\title{
THE STRATEGY TO IMPROVETHE COMPETITIVENESS OF INDONESIAN SEAWEEDS IN GLOBAL MARKET
}

\author{
Delu Damelia and Etty Soesilowati
}

Faculty of Economics, Semarang State University

C 6 Building,.Firs floor, Sekaran Campus. Semarang State University. Indonesia.

E-mail: ddanggodo@gmail.com

E-mail: ettysoesilowati@mail.unnes.ac.id

Recieved: August 2016; Accepted: December 2016

\begin{abstract}
This research is aimed to know the position of Indonesian seaweedsexports'competitiveness in global market, as well as the strategy to improve it. The research uses a quantitative approach, which specifically employs time series type that has been done within 10 years period (2003-2012). The data used are the data of seaweed product by the code product of HS 121220 Seaweeds and other algae (fresh or dried), HS 121221 Seaweedsfit for human consumption, HS 121229 Seaweeds and other algae unfit for human consumption. The data includes the value of Indonesian seaweeds exports commodity, the total of Indonesian exports, the value of seaweeds in global exports, thetotal of global exports, Indonesian seaweeds imports, Indonesian seaweeds production, and Indonesian seaweeds exports. The data is analyzed using Revealed Comparative Advantage (RCA), Import Dependency Ratio (IDR), Specialized Trading Index (ISP), Commodity Concentration Index (CCI), alongside with Strengths, Weaknesses, Opportunities, and Threats. The result shows that: (1) The RCA of seaweeds commodity though fluctuating but relatively increasing; (2) The Import Dependency Ratio of Indonesian seaweeds though fluctuating but relatively increasing, the fluctuation is due to their inability to produce plus value of ferments; (3) Index of Specialized trading appears to be positive; (4) Commodity Concentration Index of exports and imports though fluctuating but relatively increasing; (5) Indonesia can employ Rapid Growth Strategy. The result recommends Indonesian government to improve the quality of seaweeds products specifically using distribution improvements from farmers to consumer both in industrial scope and domestic consumer.
\end{abstract}

Keywords: Competitiveness, Indonesian Seaweeds, Global Market JEL Classification: G30, 0130

\section{Background}

Indonesia is an archipelagic country that has17.504 islands and has length of beaches of around $81.000 \mathrm{~km}$. Its marine and fishery potential reaches 3.000 trillion per year, but only $7,5 \%$ of the potential is being utilized. The result of fishery sector gives contribution of $2,15 \%-2,77 \%$ towards PDB (Gross Domestic Product) based on the price during the year period of $2004-2008$ (Kementrian Kelautan \& Perikanan, 2008).
The vast potential shown by the seaweeds commodity is approximately 2,6 million hectare with more than 2 million hectare considered very potential. It can be seen by the dried seaweeds production potential that can reach roughly about 17,774 million tons per year. Given the average price of seaweeds product is $\mathrm{Rp} .9 .000 / \mathrm{kg}$, the income will reach about $\mathrm{Rp} .159 .970$ trillion.

On the other side, the demand of seaweeds increases alongside with the increase 
of people, industrial development, and the world community's tendency to go back to natural products (Anggadiredja et al., 2006). Approximately, seaweeds' potential in global market increases around 10 percent each year, specifically for ferments SRC jelly and algaefor industrial grade.

Table 1. Indonesian Seaweeds Exports Data

\begin{tabular}{ccc}
\hline \multirow{2}{*}{ Year } & \multicolumn{2}{c}{ Exports } \\
\cline { 2 - 3 } & Tons & Value (US\$ 1000) \\
\hline 2007 & 94.073 & 57.522 \\
2008 & 99.949 & 57.522 \\
2009 & 94.003 & 87.773 \\
2010 & 123.074 & 135.940 \\
2011 & 159.075 & 157.587 \\
\hline
\end{tabular}

Source: Kementrian Kelautan \& Perikanan , 2014

The improvement of seaweeds exports quality but second based on its exports value. The shown by its increased volume brings Indonesian total and value of 5 leading countries of seaweeds seaweeds to international market. Indonesian commodity can be seen on Table 2 and 3 . seaweed is considered first based on its exports

Table 2. Five Leading Countries for Seaweeds Exports Quantity (Based on Tons)

\begin{tabular}{lccccccc}
\hline \multicolumn{1}{c}{ Countries } & $\mathbf{2 0 0 5}$ & $\mathbf{2 0 0 6}$ & $\mathbf{2 0 0 7}$ & $\mathbf{2 0 0 8}$ & $\mathbf{2 0 0 9}$ & $\mathbf{2 0 1 0}$ & $\mathbf{2 0 1 1}$ \\
\hline Indonesia & 69.226 & 95.588 & 94.073 & 99.949 & 94.003 & 123.074 & 159.075 \\
Chile & 46.997 & 41.498 & 51.953 & 55.622 & 56.194 & 65.173 & 67.770 \\
China & 49.114 & 46.998 & 41.710 & 35.725 & 30.353 & 33.053 & 36.268 \\
Republicof Korea & 30.294 & 19.909 & 13.371 & 17.625 & 14.616 & 20.547 & 27.879 \\
Philippines & 21.402 & 18.948 & 12.032 & 13.423 & 10.734 & 17.150 & 26.272 \\
Peru & 5.587 & 6,494 & 8.979 & 21.835 & 12.327 & 22.783 & 25.257 \\
\hline
\end{tabular}

Source: Food and Agricultural Organization, 2014

Table 3. Five Leading Countries for Seaweeds Exports Value (Based on US \%1000)

\begin{tabular}{lccccccc}
\hline \multicolumn{1}{c}{ Countries } & $\mathbf{2 0 0 5}$ & $\mathbf{2 0 0 6}$ & $\mathbf{2 0 0 7}$ & $\mathbf{2 0 0 8}$ & $\mathbf{2 0 0 9}$ & $\mathbf{2 0 1 0}$ & $\mathbf{2 0 1 1}$ \\
\hline China & 108.945 & 119.545 & 119.812 & 124.322 & 120.004 & 141.818 & 188.689 \\
Indonesia & 35.555 & 49.586 & 57.522 & 110.153 & 87.773 & 135.940 & 157.587 \\
Republic of Korea & 87.857 & 88.486 & 74.415 & 95.486 & 79.561 & 96.919 & 136.847 \\
Chile & 35.604 & 33.604 & 41.500 & 54.603 & 60.811 & 71.211 & 81.161 \\
Philippines & 28.629 & 25.327 & 21.635 & 25.361 & 12.710 & 38.237 & 56.070 \\
Peru & 2.177 & 2.595 & 4.003 & 14.085 & 8.578 & 14.831 & 16.814 \\
\hline
\end{tabular}

Source: Food and Agricultural Organization, 2014

This research is objected to know the competitiveness of seaweeds in international market and to develop a strategy to improve it. Hopefully, the result gained is able to contribute in terms of idea and information for the policy makers.

\subsection{Literature Review}

The demand of particular commodity is highly influenced by its price. The lower the price, the more products will be requested, on the contrary, the higher the price, the lesser product will be requested.Beside the price of the products, 
other factors that may influence the demand of particular products are income, the price of other similar products, preference, and expectation.

On the other side, the quantity of the promoted products also has positive relationship with the market price. Beside price, the promoted products will also be influenced by the production cost and the price of similar products. The production price depends on several factors which are the availability of technology, price, and input quantity demanded by the corporation. A country is better to produce the most efficient products that are considered better than the other countries. In terms of technology, emphasize on the importance of technology in determining the industrial factor and trading pattern of a particular country.

Furthermore, the important function of exports component to the country's economy is that the particular country gets national income, thus will increase the total output and the rate of economic growth. A country can export its products to other countries if the products are demanded by other countries, or if other countries are unable to produce or its production is not sufficient to fulfill the domestic need.

The result of the research done by Erizal Mahatma and Miftah Farid (2013) shows that the cultivation of Indonesian seaweeds has a high competitiveness, though farmers do not have input subsidiary and protection facilities from the government. Farmers are able to reach directly to the exporters. The network that ends in the exporters' party is a very superior and efficient network.

The research done by Rajagukguk, Mark Majus (2009) which analyze the competitiveness of Indonesian seaweeds in international market also shows that Indonesian seaweeds do have international market. The potential of the rich natural resources of Indonesia supports Indonesia as worlds' producer and exporters of seaweeds. The exchange value and GDP (Gross Domestic Product) per capita of the destined country also influences Indonesian seaweeds market.
Business of seaweed aquaculture in Kupang Regency is conducted by home industry, where the whole family members can actively play role in every business stages, starting from preparing cultivation area to harvest delivery. The average of total working hours for women is 210.47 and for men is 218.77, while the children does not overwork with total time of 68.13 (Sunadji, 2008)

Most of seaweed farmersin Indonesia had two main livelihood activities, namelyseaweed farming mainly Eucheuma cottonii and sustenance fishing activity with seaweed farming giving bigger contributions to household income. They were usually supported by particular middlemen to meet the capital and marketing requirements of their production of dried seaweed. Fishermen couldusually get capital investment and daily operational funds through a quick process from the middlemen, without any interest payment. Thus, the middlemen occupy a crucial position in the production and marketing dynamics of the seaweed trade in the study area (Zamroni A and Masahiro Yamada, 2013).

\section{Research Methodology}

This research employs quantitative approach. The data used is the secondary data during 10 years period $(2003-2012)$ that includes: (a) The value of Indonesian seaweeds commodity export; (b) The total of Indonesian exports value; (c) The value of world's seaweeds exports; (d) The total value of world's exports; (e) Indonesian seaweeds imports; (f) The production of Indonesian seaweeds; (g) The exports of Indonesian seaweeds; and (h) Indonesian total exports.

The data is analyzed using Revealed Comparative Advantages (RCA), Import Dependency Ratio (IDR), Index of Specialized Trading (ISP), Commodity Concentration Index (CCI), and SWOT analysis. Revealed Comparative Advantage (RCA) is used to discover whether particular product hascompetitiveness with similar products from another country. 


\section{Jurnal Ekonomi Pembangunan, 17 (2), December 2016, 193-204}

$\mathrm{X}_{I K}$ : The exports value of productIcountry $\mathrm{K}$

$\mathrm{X}_{M T}$ : The total exports of country $\mathrm{K}$

$\mathrm{X}_{W K}$ : The exports value of product $\mathrm{I}$ in the world

$\mathrm{X}_{W M}$ : The total of world's exports value

If RCA index is more than 1, it shows that particular product in particular country has a strong competitiveness. On the contrary, RCA index of less than 1 shows that the product has no competitiveness.

$I D R=\frac{\text { Imports }}{\text { Production }+ \text { Impors }- \text { Exports }} \times 100$

Import Dependency Ratio (IDR) is used to discover Indonesian dependency toward seaweeds imports.

$I S P=\frac{\left(X_{i n}-M_{i n}\right)}{\left(X_{i n}+M_{i n}\right)}$

$\mathrm{X}_{\mathrm{in}}=$ Exports value of product $\mathrm{I}$ in particular country

$\mathrm{M}_{\text {in }}=$ Imports value of product $\mathrm{I}$ in particular country

The ISP value:

ISP $=-1,0 \quad$ (does not have exports value at all)

ISP $=-1,0 \mathrm{~s} / \mathrm{d} 0$ (particular commodity has a weak competitiveness due to imports > exports)

ISP $=0-1$ (particular commodity has a strong competitiveness due to exports $>$ imports)

$\mathrm{ISP}=1 \quad$ ( Particular country does not have imports for particular commodity)

Commodity Concentration Index is used to discover the prospect on whether the product will be concentrated in one type of market or spreading.

$C_{j x}=100 . \Sigma\left(\frac{X_{i j}}{X_{j}}\right)^{2}$

$\mathrm{C}_{\mathrm{JX}}=$ Concentration index of exports group concentration commodity

$\mathrm{X}_{\mathrm{IJ}}=$ Exports value of country $\mathrm{j}$ for commodity groupi
$X_{j}=$ Total value of exports of country $j$

Commodity Concentration Index of imports is as follow:

$C_{j m}=100 . \Sigma\left(\frac{M_{i j}}{M_{j}}\right)^{2}$

$\mathrm{C}_{\mathrm{Jm}}=$ Concentration index of imports of commodity group

$\mathrm{M}_{\mathrm{IJ}}=$ Imports value of country $\mathrm{j}$ for group commodityi

$M_{j}=$ Total value of imports of country $j$

SWOT analysis is the analysis of both internal and external organization which thus be used as the foundation to develop a strategy and working program. Internal analysis includes the assessment towards Strengths and Weaknesses, while external analysis includes Opportunities and Threats factors assessment.

\subsection{Result and Analysis}

There are three types of seaweeds that are cultivated in Indonesia, which are Gracillaria sp., Euchema sp. , and Sargasum. The Sargasumtype is a rare type and thus protected. In Indonesia, Gracillaria sp. and Euchema sp. are the types of seaweeds which have high economic value since it produces jellies and ferments. Seaweeds are also needed in food industry, cosmetics, and pharmacy (Kementrian Kelautan \& Perikanan, 2013). The following graph is the result of Indonesian seaweeds cultivation result dates in 2003 until 2012.

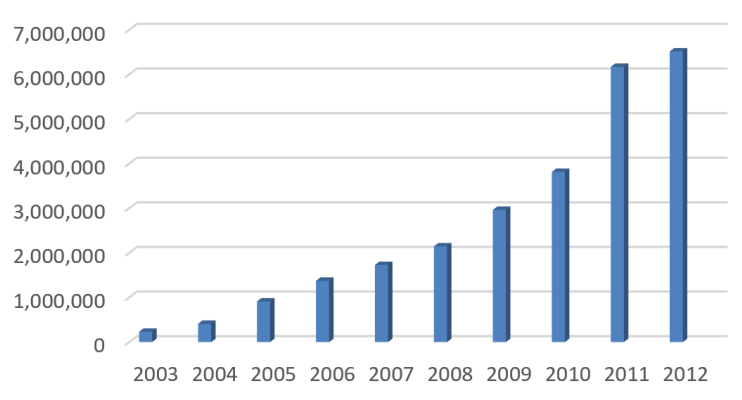

Figure 1. Indonesian Seaweeds Production Source: Kementrian Kelautan \& Perikanan, 2013 
The position of Indonesian exports alongside other big seaweeds producer countries (calculated based on tons) shows that Indonesia is in the first position followed by Chile and China as the second and the third place.

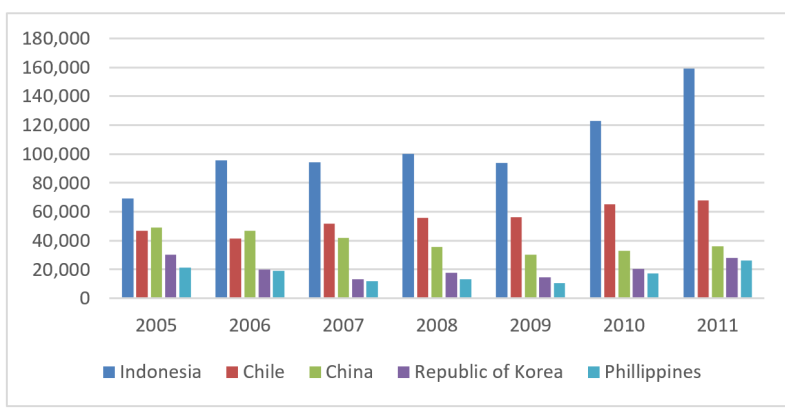

Figure 2. Five Leading Countries of Seaweeds Exporters (based on tons)

Source: Kementrian Kelautan \& Perikanan, 2012

Indonesia becomes the first position as exporter of seaweeds in the world. Indonesia is superior in terms of quantity though is not followed by the trading position in international market based on unit value. In terms of unit value exports, Indonesian is in the second place after China.

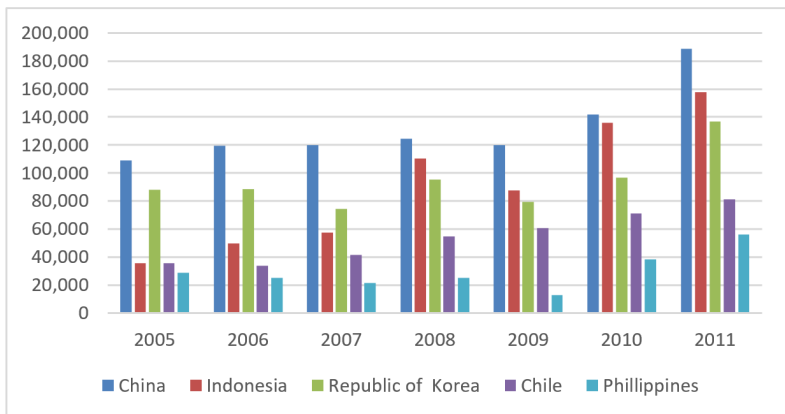

Figure 3. Five Leading Countries in Seaweeds Exports Value (based on US \$1000)

Source: Kementrian Kelautan \& Perikanan, 2012

The calculation of RCA seaweeds commodity in the year $2003-2012$ is as follow:

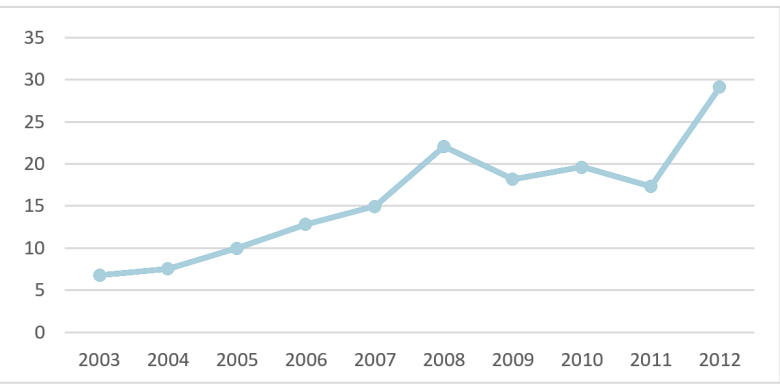

Figure 4.Revealed Comparative Advantageof Indonesian Seaweeds 20032012

The improvement of Indonesian seaweeds' competitiveness keep increasing from 2003 to the number of 22.06 in 2008, while in 2009 decreases to 18.18 and keep fluctuating and increases again in 2012 to 29.16. The improvement of the dependency value of Indonesian seaweeds within the period of 2003 2012 is as follow:

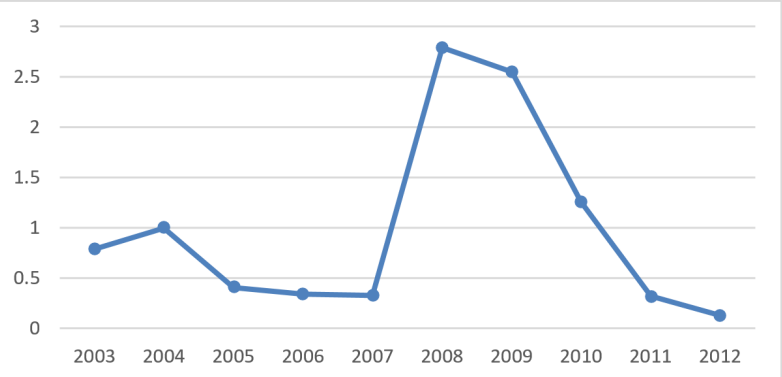

Figure 5. The Dependency Ratio of Indonesian Seaweeds Imports by $2003-2012$

The Index of Specialized Trading is used to analyze the position or step of particular product's development. If the value of Specialized Index Trading is positive $(0<\mathrm{ISP} \leq 1)$, the particular commodity has a strong competitiveness or has the tendency as the commodity exporters. On the contrary, if the competitiveness is considered weak or the country relatively acts as the importer, the value of the index will appear negative $(-1 \leq \mathrm{ISP}<0)$. The result analysis of Indonesian Specialized Trading Index regarding 
their seaweeds commodity by $2003-2012$ is as follow:

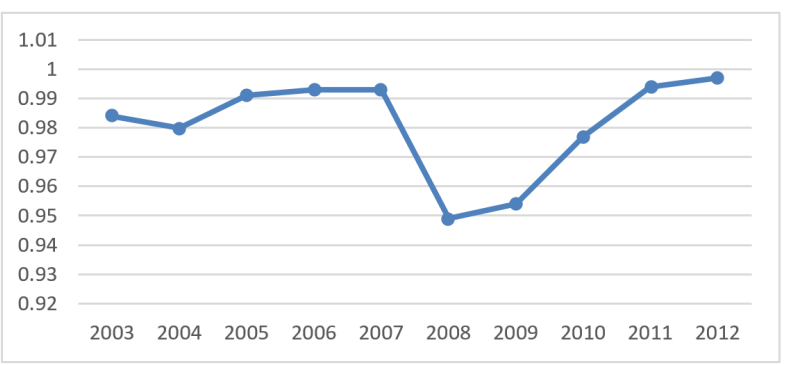

Figure 6. The Index of Specialized Trading for Indonesian Seaweeds by 2003 - 2012

The index shows that Indonesia has positive value, thus means that Indonesian seaweeds have a strong competitiveness in the market. Commodity Concentration Index is used to know the prospect of seaweeds in global market. The figure bellow shows the result of Commodity Concentration Index for Indonesian seaweeds exports by $2003-2012$

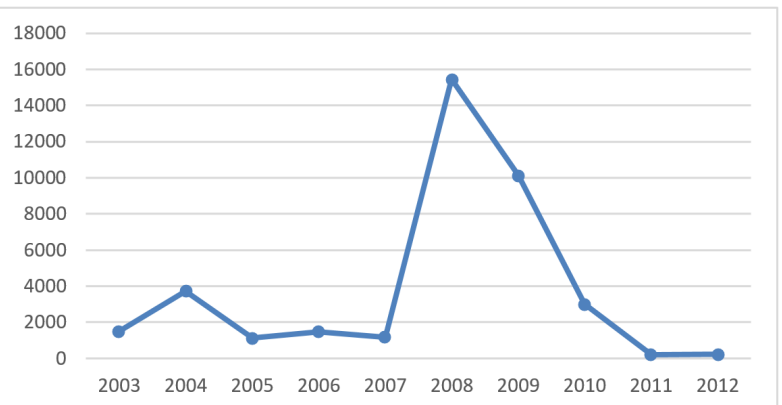

Figure 7. Commodity Concentrated Index for Indonesian Seaweeds Exports by 2003 2012

The Commodity Concentration Index of Indonesian seaweeds export is high due to the value of index above 100 . However, the meaning of the value index of commodity concentration on imports and exports is different. The bigger the Commodity Concentration Index of Indonesian seaweeds export the better it is for Indonesia. However, the bigger the Commodity Concentration Index of Indonesian seaweeds import the worse it is for Indonesia.

\section{Discussion}

Indonesian seaweeds has competitiveness since the index value of comparative advantage is above 1 ( $\mathrm{RCA}>1)$. However, it appears that each year the value is fluctuating, thus shows the decrease of its competitiveness quality. The overall cause of decrease in competitiveness quality is based on Indonesian ability to trade their seaweeds products that can be seen by its total production. Indonesian seaweeds have comparative advantage that is more efficient than other countries. It is believed that Indonesian seaweeds havecompetitiveness due to some supporting factors such as: the length of Indonesian sea, Indonesian climate that matches with seaweeds cultivation, a shorter harvesting period of Indonesian seaweeds, and the quality of Indonesian raw seaweeds product.

The dependency ratio of Indonesian imports is also fluctuating and it is once increased when Indonesia is contributing in ferments imports. The increase is caused by the increasing of local demands to ferment products due to industrial needs in local industries. The imports dependency based on Hecker-ohlin justifies that it is caused by the lack of processing technology that Indonesia has specifically to produce ferments product.

The Index of Specialized Trading for Indonesian seaweeds shows that Indonesia has competitiveness since the index shows during the period of $2003-2012$ is positive $(0<\mathrm{ISP} \leq 1)$. However, the competitiveness of Indonesian seaweeds based on the index is also seen to be fluctuating. Overall, Indonesia is a country with surplus value in terms of seaweeds trading within the year 2003-2012 based on the index of specialized trading.

The Exports Concentration Index of Indonesian seaweeds also appear to be fluctuating due to the lack of demands in the global market and the lack of local production sufficiency. Indonesia also has the competitiveness of raw seaweeds exports but cannot perform well in terms of ferments due to the unavailability of technology to produce it. The index of imports 


\section{Jurnal Ekonomi Pembangunan, 17 (2), December 2016, 193-204}

concentration of Indonesian seaweeds is also fluctuating, though Indonesia used to increase its imports due to the insufficiency of local production and unavailability of seaweeds plus value (ferments). However, though fluctuating, based on the Commodity Concentration Index, Indonesia has competitiveness since the overall exports are always increasing and imports are always decreasing. However, the increased exports are always based on raw seaweeds commodity while the imports are always ferments product.

\subsection{SWOT Analysis}

The SWOT analysis studies on the phenomenon qualitatively which is based on the logic in maximizing the strengths and opportunities while at the same time minimalizing weaknesses and threats. The following table shows the details of strengths, weaknesses, opportunities, and threats both internally and externally. The strategy to improve Indonesian seaweeds' competitiveness is also determined.

Table 3. Internal and External Factors of Indonesian Seaweeds Commodity

\begin{tabular}{cc}
\hline Internal Factors & External Factors \\
\hline Strengths & Opportunities \\
\hline
\end{tabular}

1. The country consists of 17.504 islands with its sea border lengths of $81.000 \mathrm{~km}$ thus it has maritime potential that can be developed

1. The use of seaweeds are highly varied

2. The worlds' demand fulfillment opportunity on seaweeds are widely open

2. Indonesian seaweeds has the best nutrients

3. The harvesting period of Indonesian seaweeds is very short (45 days of harvest period)

3. The demand of world market to seaweeds products increases each year alongside with the development of seaweeds-based industry

4. Indonesian seaweeds has high competitiveness based on two analyses (RCA and Index for Specialized Trading)

4. The tendency of people to go green (back to natural products)

$$
\text { Weaknesses }
$$

Threats

1. Indonesian seaweeds does not have competitive advantage, since they could not produce plus value

2. Logistic system of Indonesian seaweeds products makes the products cannot be distributed well

1. The unstable price since seaweeds are tertiary products

2. Ships activity close to the seaweeds plantation causes the lack of sunlight got by seaweeds

3. The policy made by government is not suitable since the government does not comprehend the real condition of Indonesian seaweeds

4. Indonesia is still depended on imports of seaweeds

3. A material that can replace the advantage of seaweeds consumption is available

4. Seaweeds-related disease disturbs the production

Based on the SWOT mapping of Indonesian

$0,10=$ average seaweeds, the weights and ratingdeterminer for

$0,05=$ bellow average

competitive strategies based on the questionnaire and interview are as follow:

The weights is determined by the following description:

$0,20=$ very strong

$0,15=$ above average

The rating is determined by the following description:

$4=$ major strength

$3=$ minor strength

$2=$ minor weakness

$1=$ mayor weakness 


\section{Jurnal Ekonomi Pembangunan, 17 (2), December 2016, 193-204}

After the mapping, the following step will be the analysis using SWOT that can create possibility of alternative strategies of competitiveness. Beside looking at the internal and external factors, Indonesian seaweeds' competitiveness strategies also can be determined by Internal Factor Analysis Summary (IFAS) and External Factor Analysis Summary (EFAS).

Table 4. The result of Internal Factor Analysis Summary (IFAS) Calculation

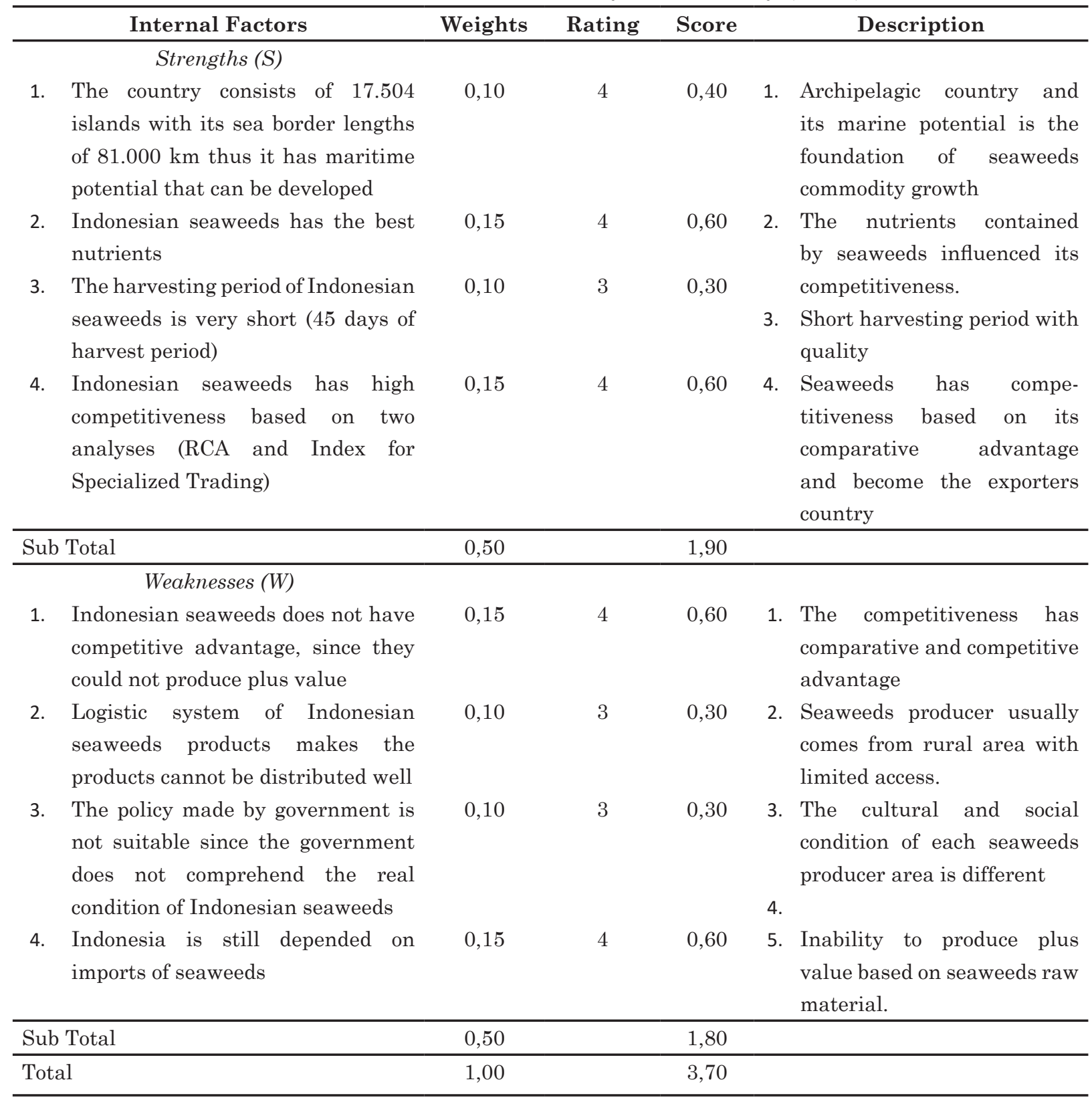

Furthermore, the calculation of EFAS is structured using the same method as the table above. The result of EFAS calculation is as follow: 
Avalaible online at http://journals.ums.ac.id

Jurnal Ekonomi Pembangunan, 17 (2), December 2016, 193-204

Table 5. The Result of External Factor Analysis Summary (EFAS) Calcullation

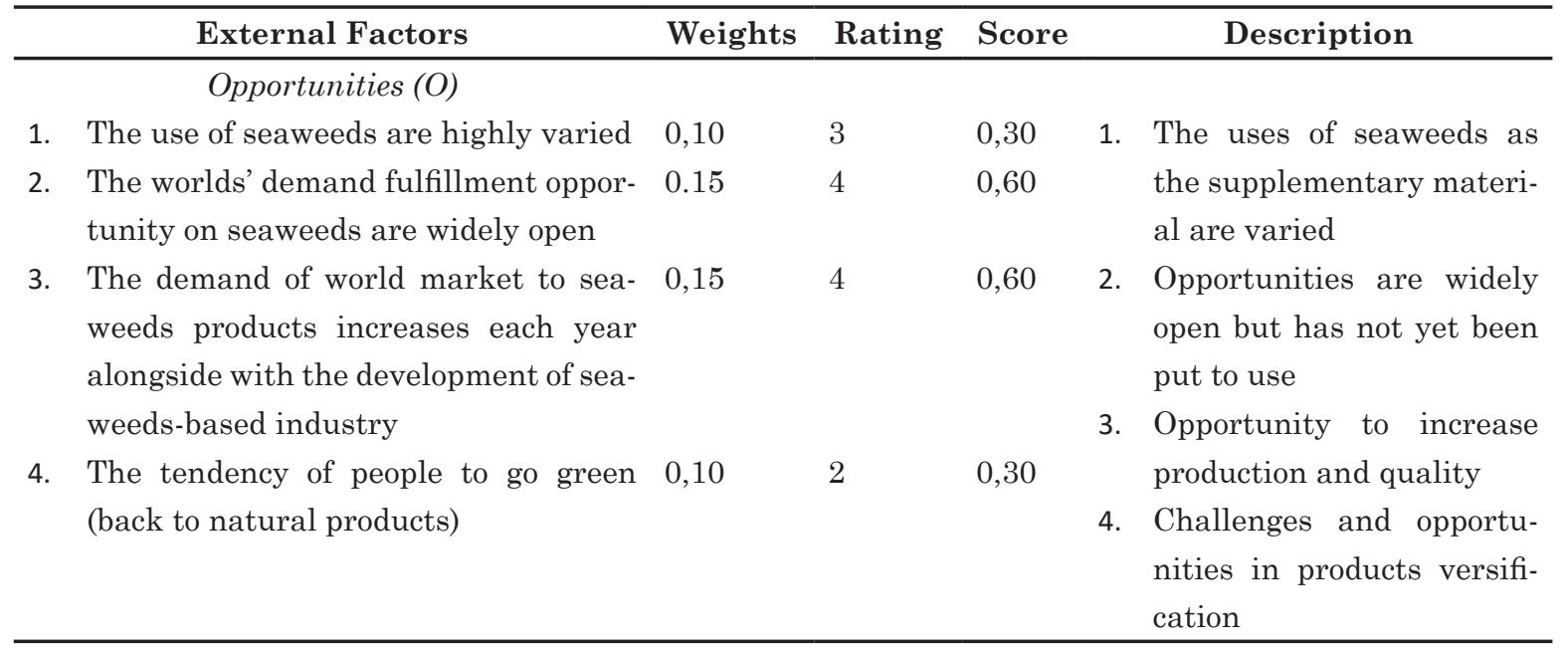

\begin{tabular}{lll}
\hline Sub Total & 0,50 & 1,80 \\
\hline
\end{tabular}

\section{Threats (T)}

1. The unstable price since seaweeds are 0,15 tertiary products

2. Ships activity close to the seaweeds 0,10 plantation causes the lack of sunlight got by seaweeds

3. A material that can replace the ad- 0,15 vantage of seaweeds consumption is available

4. Seaweeds-related disease disturbs the 0,10 production

\begin{tabular}{lll}
\hline Sub Total & 0,50 & 1,70 \\
\hline Total & 1,00 & 3,50 \\
\hline
\end{tabular}

Based on IFAS table, the Strengths factor has 1,90 score while Weaknesses has 1,80 score. It can be seen that Indonesian seaweeds has higher score in Strengths compared to its Weaknesses thus revealed its competitiveness. Moreover, the EFAS table provides information that Opportunities gain score of 1,80 while Threats receive 1,70 score meaning that the opportunities of Indonesian seaweeds are relatively high than its threats.
In conclusion, the result internal and external factors calculation provides these following series of score:

$$
\begin{array}{ll}
\text { - } & \text { Strengths }(\mathrm{S})=1,90 \\
\text { - } & \text { Weaknesses }(\mathrm{W})=1,80 \\
\text { - } & \text { Opportunities }(\mathrm{O})=1,80 \\
\text { - } & \text { Threats }(\mathrm{T})=1,70
\end{array}
$$

Based on the score, a recap table of IFAS and EFAS score can be concluded as follow:

Table 6. Final Recap of EFAS and IFAS Score Calcullation

\begin{tabular}{ccc}
\hline Internal Score & External Score & Strategy choices \\
\hline$S>W(+)$ & $O>T(+)$ & GROWTH \\
$1,90>1,80$ & $1,80>1,70(+)$ & SURVIVAL \\
$S<W(-)$ & $O<T(-)$ & \\
\hline
\end{tabular}


Avalaible online at http://journals.ums.ac.id

Jurnal Ekonomi Pembangunan, 17 (2), December 2016, 193-204

\begin{tabular}{ccc}
\hline Internal Score & External Score & Strategy choices \\
\hline$S>W(+)$ & $O<T(-)$ & DIVERSIFICATION \\
$S>W(-)$ & $O>T(+)$ & STABILITY \\
\hline
\end{tabular}

To determine the strategy that is more specific based on the score, a diagram can be drawn to give better view on strategy choices. The table shows that the strategy choice falls to Growth strategy, thus the matrix will show related to Growth Strategy more specifically. The weights and score above shows that Strengths factor is bigger than Opportunities. The result can be seen in the following matrix:

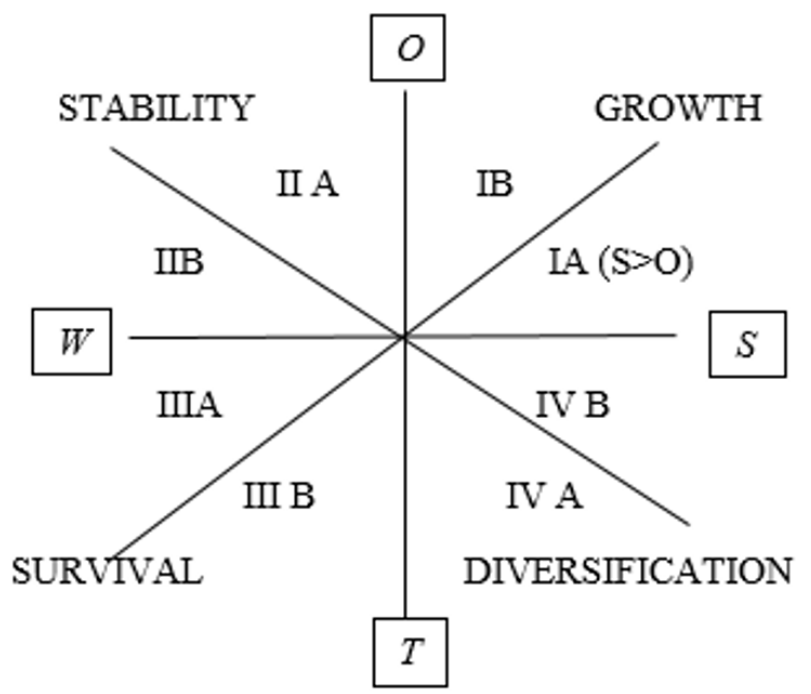

Figure 9. Strategy Choices Matrix

The explanation following the matrix can be seen in the table below:

Table 7. Explanation of the Matrix Result

\begin{tabular}{lccl}
\hline \multicolumn{1}{c}{ Strategy techniques } & Score & Quadrant & \multicolumn{1}{c}{ Strategy choices } \\
\hline Growth & $S>O$ & I A & Rapid Growth \\
& $S<O$ & I B & Stable Growth \\
Survival & $W>T$ & III A & Turn Around \\
& $W<T$ & III B & Guerilla \\
Diversification & $S>T$ & IV B & Conglomerate \\
& $S<T$ & IV A & Concentric \\
Concentric & II A & Aggressive Maintenance \\
& $O>W$ & II B & Selective Maintenance \\
\hline
\end{tabular}

The SWOT analysis shows that the Strengths of Indonesian seaweeds are greater than the Opportunities ( $>0$ ), thus it can be concluded that the strategy to strengthen its competitiveness is Rapid Growth Strategy. Rapid Growth Strategy is a strategy that is designed to achieve growth in selling gross, assets, profit or the combination of three. The Strength means 
the high production growth that cannot utilize Opportunities available. The Rapid Growth Strategy is employed by achieving growth in some factors that supports Indonesian seaweeds' competitiveness, such as total production, the cultivation land availability, exports growth, and post-harvest processing technology.

The Rapid Growth Strategy needs to be synergize with policies made by government that are suitable for the condition on the field. For example, if the weakness lies in the logistic system due to inaccessible area of the seaweeds plantation (since usually seaweeds are cultivated in rural area of the Eastern part of Indonesia), thus the government need to facilitate farmers in distributing their production results to the consumer or related industries.

To strengthen the seaweed industry and carrageenanbusiness in Indonesia, a number of key issues need to seriously be addressed, such as improvement of seaweed quality (use of good seedlings, harvest at sufficient cultivation age, reduction of impurities), provision of financial sources with good accessibility by the seaweed farmers, establishment of strong mutual cooperation between the farmers, processing industries and exporters, and establishment of an industrial standard for seedlings, cultivation and harvest methods, and postharvest handling in order to minimize the variability in the seaweed quality. It is also necessary to regulate the marketing mechanism of seaweed raw materials as to establish a healthy competition among the seaweed collectors, processors and exporters. By doing so, it is expected that better carrageenan yield and quality will be resulted and, therefore, supporting the development of good and competitive seaweed industry as well as the carrageenan industry and business in Indonesia (Djusdil Akrim. 2014)

\section{Acknowledgement}

Research financed by the Indonesian Ministry of Research Technology and Higher

\section{Conclusion}

The result and the discussion that employs RCA, IDR, ISP, CCI, and SWOT analysis provides these following conclusion: (1) Indonesian seaweeds has good competitiveness before it is appointed as superior commodity or after being appointed as superior commodity (2007) since the RCA commodity value is above $1(\mathrm{RCA}>1)$ ; (2) Import Dependency Ration of Indonesian seaweeds shows that Indonesia still depends on imports due to their inability to produce ferments products while the need of ferments for industries keep increasing; (3) Indonesia is one of the exporter countries in the world. The Index of Specified Trading by the period of $2003-2012$ shows positive value $(0<\mathrm{ISP} \leq 0)$; (4) Commodity Concentration Index for imports and exports is fluctuating but keeps showing improvements; (5) The strategy to improve Indonesian seaweeds' competitiveness can be done using Rapid Growth Strategy, which means Indonesia need to improve its product quality and utilize the opportunities factor available

\section{Suggestion}

Based on the conclusion, the suggestions that are probable to be done are as follow: (1) Indonesian government is hoped to improve Indonesian seaweeds' quality both by making policy or creating better distribution network from farmers to consumers (both industrial and domestic). It is hoped that government enables ferments industries since it is the plus value of seaweeds commodity; (2) Seaweeds farmers are expected to produce high quality of seaweeds product periodically; (3) Any stakeholder in seaweeds market is expected to coordinate well in terms of increasing the products' competitive advantage alongside with its comparative advantage, hence Indonesian seaweeds product will have high and strong competitiveness in global market. 
Avalaible online at http://journals.ums.ac.id

Jurnal Ekonomi Pembangunan, 17 (2), December 2016, 193-204

\section{Reference}

Anggadiredja, JT; Zatnika, A; Purwoto, H; Istini,

S. 2006. Seri Agribisnis; Rumput Laut. Jakarta: PenebarSwadaya.

Djusdil Akrim. 2014. The Seaweed Business

Development in Indonesia. Journal of

Shipping and Ocean Engineering 4 (2014) 198-202

Erizal Mahatma, Farid Miftah. 2013. "Daya Saing dan Pemasaran Rumput Laut Kasus: Kabupaten Jeneponto, Sulawesi Selatan. Jurnal Litbang Perdagangan. Vol.7. Jakarta: Kementrian Perdagangan

Food and Agricultural Organization of The United Nations. Data of Seaweeds Exports http://faostat.fao.org/faostat/, Retrieved on November 14, 2014.

Kementerian Kelautan dan Perikanan, Buku Statistik Kelautan dan Perikanan . 2014.

http://statistik.kkp.go.id/, Retrieved on November 10,2014

Retrieved on November 9, 2014
- 20012. http://statistik.kkp.go.id/, Retrieved on November 11, 2014

2008. http://statistik.kkp.go.id/, Retrieved on November 15, 2014

Rajagukguk, Mark Majus. 2009. "Analisis Daya Saing Rumput Laut Indonesia di Pasar Internasional". Skripsi. Bogor: Fakultas Ekonomi dan Manajemen IPB

Sunadji. 2008. Development Strategy of Seaweed Aqua Culture Business in Kupang Regency, East Nusa Tenggara Province, Indonesia. Journal of Agricultural Studies ISSN 21660379 2014, Vol. 2, No. 1

Zamroni A and Masahiro Yamada, 2013, An assessment of farm-to-market link of Indonesian dried seaweeds: Contribution of middlemen toward sustainable livelihood of small-scale fishermen inLaikang Bay . African Journal of Agricultural Research Vol. 8(17), pp. 1709-1718, 9 May, 2013 